\title{
KONSEP DISTRIBUSI PENDAPATAN DALAM ISLAM
}

\author{
M oh. A h. Subhan ZA \\ Program Studi Ekonomi Syariah \\ Fakultas A gama Islam U niversitas Islam L amongan \\ e-mail: subhanza@ymail.com
}

\begin{abstract}
The main problem of social life in the community is about how to make the allocation and distribution of income well. Inequality and poverty basically arise not because of the difference of anyone's strength and weakness in getting livelihood, but because of inappropriate distribution mechanism. With the result that wealth treasure just turns on the rich wealthy, which is in turn, results in the rich get richer and the poor get poorer. Therefore, a discussion on distribution becomes main focus of theory of Islamic economics. M oreover, the discussion of the distribution is not only related to economic issues, but also social and political aspects. On the other side, the economic vision of Islam gives priority to the guarantee of the fulfillment of a better life. Islam emphasizes distributive justice and encloses, in its system, a program for the redistribution of wealth and prosperity, so that each individual is guaranteed with a respectable and friendly standard of living. Islam recognizes private property rights, but the private property rights must be properly distributed. The personal property is used for self and family livelihood, for investment of the working capital, so that it can provide job opportunities for others, for help of the others through zakat, infaq, and shodaqoh. In this way, the weal th not only rotates on the rich, bringing on gap in social life.The problem of wealth distribution is closely related to the welfare of society. Therefore, the state has a duty to regulate the distribution of income in order that the distribution can be fair and reaches appropriate target. The state could at least attempt it by optimizing the role of BAZ (Badan A mil Zakat) and LAZ (Lembaga A mil Zakat) which has all this time been slack. If $B A Z$ and $L A Z$ can be optimized, author believes that inequality and poverty over time will vanish. This is because the majority of Indonesia's population is Muslim.
\end{abstract}

Keywords: distribution of income, State' role, Islamic economics

\section{Pendahuluan}

A gama Islam adalah agama yang komprehensif, agama yang mengatur seluruh aspek kehidupan manusia, termasuk dalam bidang ekonomi. Salah satu tujuannya adalah untuk mewujudkan keadilan dalam pendistribusian harta, baik dalam kehidupan individu maupun bermasyarakat. ${ }^{1}$ T ujuan dan nilai-nilai dari sistem ekonomi Islam adalah untuk memenuhi semua kebutuhan dari segala sektor kegiatan dan kebutuhan manusia. Untuk mencapai tujuan ini, diperlukan distribusi pendapatan yang merata sehingga bisa meningkatkan

\footnotetext{
${ }^{1}$ Veithzal Rivai dan Andi Buchari, Islamic Economics: Ekonomi Syariah Bukan Opsi, Tetapi Solusi (Jakarta: PT. Bumi A ksara), 88
} 
kesejahteraan sosial.

Salah satu masalah utama dalam kehidupan sosial di masyarakat adalah mengenai cara melakukan pengalokasian dan pendistribusian sumber daya dengan baik. Kesenjangan dan kemiskinan pada dasarnya muncul karena mekanisme distribusi yang tidak berjalan sebagaimana mestinya. M asalah ini tidak terjadi karena perbedaan kuat dan lemahnya akal serta fisik manusia sehingga menyebabkan terjadinya perbedaan perolehan kekayaan. Tetapi permasalahan sesungguhnya terjadi karena penyimpangan distribusi yang secara akumulatif berakibat pada kesenjangan kesempatan memperoleh kekayaan. Sehingga yang terjadi yang kaya akan semakin kaya dan yang miskin semakin tidak memiliki kesempatan kerja.

Distribusi menjadi posisi penting dari teori ekonomi Islam karena pembahasan distribusi bukan saja berhubungan dengan aspek ekonomi tetapi juga aspek sosial dan politik. Di sisi lain juga berkaitan dengan visi ekonomi Islam yang lebih mengedepankan adanya jaminan pemenuhan kebutuhan hidup yang lebih baik. Islam menekankan keadilan distribusi dan menyertakan dalam sistemnya suatu program untuk pembagian kembali kekayaan dan kemakmuran, sehingga tiap-tiap individu dijamin dengan suatu standar hidup yang terhormat.

\section{Pengertian dan Prinsip Distribusi Pendapatan}

Distribusi pendapatan dalam Islam merupakan penyaluran harta, baik yang dimiliki oleh pribadi atau umum kepada pihak yang berhak menerima dengan tujuan untuk meningkatkan kesejahteraan masyarakat sesuai dengan syariat Islam. Fokus dari distribusi pendapatan dalam Islam adalah proses pendistribusiannya. Secara sederhana, dapat digambarkan bahwa kewajiban menyisihkan sebagian harta bagi pihak surplus diyakini sebagai kompensasi atas kekayaanya dan di sisi lain merupakan insentif (perangsang) untuk pihak defisit. ${ }^{2}$

Titik berat dalam pemecahan permasalahan ekonomi adalah bagaimana menciptakan mekanisme distribusi ekonomi yang adil di tengah masyarakat. Distribusi dalam ekonomi Islam mempunyai makna yang lebih luas mencakup pengaturan kepemilikan, unsur-unsur produksi antara individu dan masyarakat serta anggota perserikatan, dan distribusi dalam sistem sosial.

A gama Islam memberikan kebebasan kepada umat manusia untuk memiliki kekayaan, tetapi tidak membiarkan manusia begitu saja untuk memiliki semua apa yang dia inginkan, dan menggunakan berbagai cara yang mereka kehendaki. K ekayaan memang penting tetapi yang lebih penting lagi adalah cara pendistribusiannya, karena jika distribusi kekayaan itu tidak tepat, maka sebagian kekayaan itu akan beredar di tangan orang-orang kaya saja dan mengakibatkan penderitaan pada orang-orang miskin. Oleh karena itu, kesejahteraan rakyat tidak sepenuhnya tergantung pada hasil produksi, tetapi juga tergantung pada ditribusi pendapatan yang tepat. Seperti yang diutarakan oleh Afzalur Rahman, jika suatu negara mempunyai kelebihan kekayaan, tetapi distribusinya tidak berdasarkan pada prinsip keadilan

2 Dr. Rozalinda M. Ag, Ekonomi Islam: Teori dan Aplikasinya Pada Aktifitas Ekonomi (Jakarta: PT. Raja Grafindo Persada, 2014), 131 
dan kebenaran, maka negara itu belum dianggap berhasil. ${ }^{\mathbf{3}}$

Islam memberikan batas-batas tertentu dalam berusaha, memiliki kekayaan dan mentransaksikannya. Dalam pendistribusian harta kekayaan, al-Quran telah menetapkan langkah-langkah tertentu untuk mencapai pemerataan pembagian kekayaan dalam masyarakat secara objektif, seperti memperkenalkan hukum waris yang memberikan batas kekuasaan bagi pemilik harta dengan maksud membagi semua harta kekayaan kepada semua kerabat apabila seseorang meninggal dunia. ${ }^{4}$ Begitu juga dengan hukum zakat, infaq, sadaqah, dan bentuk pemberian lainnya juga diatur untuk membagi kekayaan kepada masyarakat yang membutuhkan. Distribusi pendapatan dalam dunia perdagangan juga disyariatkan dalam bentuk akad kerja sama, misalnya distribusi dalam bentuk mudharabah merupakan bentuk distribusi kekayaan dengan sesama muslim dalam bentuk investasi yang berorientasi profit sharing. Pihak pemodal yang mempunyai kelebihan harta membantu orang yang punya keahlian berusaha, tetapi tidak punya modal. Tujuan aturan-aturan ini menurut Afzalur Rahman adalah untuk mencegah pemusatan kekayaan kepada golongan tertentu. ${ }^{5}$ Dalam al-Quran dijelaskan :

$$
\text { دولة بين الأغاء الله على رسوله من أهل القرى فلله وللرسول ولذي القرى واليتامى والمساكين وابن السبيل كي لا يكون }
$$

"A pa saja harta rampasan (fai) yang diberikan Allah kepada Rasul-Nya (dari harta benda) yang berasal dari penduduk kota-kota Maka adalah untuk Allah, untuk rasul, kaum kerabat, anak-anak yatim, orang-orang miskin dan orang-orang yang dalam perjalanan, supaya harta itu jangan beredar di antara orang-orang K aya saja di antara kamu. apa yang diberikan Rasul kepadamu, M aka terimalah. dan apa yang dilarangnya bagimu, Maka tinggalkanlah. dan bertakwalah kepada Allah. Sesungguhnya Allah A mat keras hukumannya".

A I-Q uran berulang kali mengingatkan kepada kaum muslim agar tidak menyimpan dan menimbun kekayaan untuk kepentingan mereka sendiri, tatapi mereka harus memenuhi kewajiban terhadap keluarga, tetangga, dan orang-orang yang harus mendapat bantuan. Menurut Yusuf al-Qardhawi, distribusi dalam ekonomi kapitalis terfokus pada pascaproduksi, yaitu pada konsekuensi proses produksi bagi setiap proyek dalam bentuk uang atau nilai, lalu hasil tersebut didistribusikan pada instrumen-instrumen produksi yaitu: upah, bunga, sewa dan keuntungan. ${ }^{7}$ Dari keempat instrumen tersebut di atas, bunga merupakan instrumen yang ditolak dalam Islam. Terhadap ketiga instrumen lainnya diperbolehkan selama dipenuhi syarat-syaratnya. ${ }^{8}$

Dalam ekonomi sosialis, produksi berada dalam kekuasaan pemerintah dan mengikuti

\footnotetext{
${ }^{3}$ A fzalur Rahman, Doktrin Ekonomi Islam, terj. Soeroyo dan Nastangin (Y ogyakarta: Darma Bakti Wakaf, 1985), 92

${ }^{4}$ Y usuf A I-Q ardhawi, Daur al-Qiyam wa al-A khlaq fi al-Iqtishad al-Islam (K airo: M aktabah W ahbah, 1995), 336

${ }^{5}$ A fzal ur rahman, Economic Doktrines of I slam, 317

${ }^{6}$ Q.S. al-Hasyr : 7

${ }^{7}$ Y usuf al-Q ardhawi, Daur al-Qiyam wa al-A khlaq ....., 317

8 lbid.
} 
perencanaan pusat. Semua sumber produksi adalah milik pemerintah. Semua pekerja berada dalam kekuasaan dan rezim negara. Prinsip dalam distribusi pendapatan dan kekayaan adalah sesuai apa yang ditetapkan oleh rakyat yang diwakili oleh negara dan tidak ditentukan oleh pasar. Negara yang merencanakan produksi nasional. Negara pula yang meletakkan kebijakan umum distribusi dengan segala macamnya baik berupa upah, gaji, bunga maupun ongkos sewa. Dengan dalih demi mewujudkan rasa kebersamaan, alokasi produksi dan pendistribusian semua sumber-sumber ekonomi diatur oleh negara. Lebih parah lagi, kaum sosialis tidak bisa mewujudkan keadilan bagi pekerja, bahkan justru memiskinkan masyarakat dalam semua tingkatan dan kelompoknya. ${ }^{9}$

Sesungguhnya ekonomi kapitalis telah gagal merealisasikan keadilan distribusi yang berdampak kepada penderitaan masyarakat. Dalam ekonomi kapitalis kekayaan dan kemewahan hanya dikuasai oleh sekelompok orang, sedangkan mayoritas masyarakat adalah kaum miskin. Mereka menaruh perhatian pada produksi yang menempatkan kaum kaya dengan keuntungan yang tinggi bagi pemilik modal tanpa menaruh perhatian pada pemenuhan kebutuhan masyarakat luas yang kebanyakan dari kaum fakir. Dalam sistem ekonomi kapitalis, berlangsung praktik-praktik monopoli yang sangat besar. Kadangkala, menjadi perusahaan yang bergerak dalam berbagai jenis usaha sampai sebagian perusahaan tersebut menjadi penguasa yang tidak tunduk pada aturan pemerintah setempat seperti dalam masalah pembayaran pajak. Bahkan, memaksa pemerintah tunduk pada kemauan dan kepentingan mereka dengan melakukan penyuapan secara terang-terangan. ${ }^{10}$

Berbeda dengan kedua sistem ekonomi tersebut, ekonomi Islam terbebas dari kedua kedhaliman kapitalisme dan sosialisme. Islam membangun filosofi dan sistemnya di atas pilar-pilar yang menekankan pada distribusi praproduksi dan distribusi pendapatan pascaproduksi, yaitu pada distribusi sumber-sumber produksi dan hak kepemilikannya. A pa hak dan kewajiban dari kepemilikan tersebut. Islam mempunyai perhatian terhadap pemenuhan hak-hak pekerja dan upah mereka yang adil dan setimpal dengan kewajiban yang mereka tunaikan. Secara umum, Islam mengarahkan kegiatan ekonomi berbasis akhlak alkarimah dengan mewujudkan kebebasan dan keadilan dalam setiap aktivitas ekonomi.

\section{Nilai dan Moral Distribusi Islam}

Y usuf Qardhawi dalam karyanya Daur al-Qiyam wa al-A khlaq fi al-Iqtishadi al-Islami menjelaskan bahwa distribusi dalam ekonomi Islam didasarkan pada dua nilai manusiawi yang sangat mendasar dan penting, yaitu: nilai kebebasan dan nilai keadilan. Pendapat ini didasarkan atas kenyataan bahwa Allah sebagai pemilik mutlak kekayaan telah memberi amanat kepada manusia untuk mengatur dan mengelola kekayaan disertai kewenangan untuk memiliki kekayaan tersebut. ${ }^{11}$ Sehubungan dengan masalah distribusi ini, Qardhawi menjelaskan sebagai berikut: ${ }^{12}$

\footnotetext{
9 Jaribah ibn al-Haris, Fiqih Ekonomi Umar ibn al-Khattab, terj. A smuni Sholihin Zamakhsyari (Jakarta: Khalifa, 2006), 213

${ }^{10}$ Y usuf al-Q ardhawi, Daur al-Qiyam wa al-A khlaq fi al-Iqtishad al-Islam, 318

${ }^{11} \mathrm{lbid}$., 319

12 l bid.
} 
1. Nilai K ebebasan

a. A sas K ebebasan

Kebebasan dalam melakukan setiap aktivitas ekonomi harus dilandasi keimanan kepada Allah dan ke-Esaan- $N$ ya serta keyakinan manusia kepada Sang Pencipta. Allah-lah yang menciptakan dan Dia pula yang mengatur segala urusan sehingga tidak layak lagi bagi manusia untuk menyombongkan diri serta bertindak otoriter terhadap makhluk lainnya. Tidak boleh ada pemaksaan dan penindasan karena seluruh makhluk di hadapan Tuhan adalah sama. Yang membedakan hanyalah tingkat keimanan dan ketaqwaannya.

Keyakinan manusia kepada Allah didasarkan atas persiapan material dan spiritual yang diberikan Allah kepada manusia dalam melakukan tugasnya sebagai khalifah. Kebebasan manusia adalah sesuatu yang tidak dapat dipisahkan dengan kehidupannya. Seorang yang terbelenggu tidak akan produktif. Islam memberikan kebebasan kepada manusia untuk berusaha, memiliki, mengelola dan membelanjakan hartanya sesuai dengan peraturan yang ditetapkan oleh Allah sehingga manusia pantas dimuliakan dan menerima amanah dari Allah yang harus dipertanggungjawabkan di Hari Kemudian.

b. Bukti-bukti kebebasan

1) Hak milik pribadi

Kepemilikan adalah suatu bukti prinsip kebebasan. Seorang yang memiliki suatu benda dapat menguasai dan memanfaatkannya. Ia dapat pula mengembangkan hak miliknya dengan cara-cara yang dibenarkan Islam. Islam melindungi hak milik pribadi dari perbuatan zalim seseorang dan menganjurkan untuk mempertahankan hak miliknya. Kebebasan mengharuskan seseorang untuk menanggung risiko sesuai dengan apa yang dilakukan dan memberikan hak orang lain yang terdapat di dalam hartanya.

2) W arisan

Disyari'atkannya warisan adalah sebagai pencerminan kebebasan. Di mana seseorang dapat melestarikan dan mengelola secara berkesinambungan apa yang menjadi miliknya. Perolehan hak milik dari pemilik yang lama kepada penggantinya dapat terjadi dalam dua hal, yaitu: melalui warisan dan wasiat. Kedua hal ini diakui oleh syar'i dengan maksud untuk memelihara kemaslahatan individu, keluarga dan masyarakat.

Kemaslahatan individu dapat diperoleh dengan memenuhi keinginannya serta menjaga kepentingannya dari perampasan hak yang merupakan salah satu hikmah dsyari'atkannya wasiat dan waris. Kedua hal tersebut dapat pula menguatkan hubungan keluarga dan saling tolongmenolong dan saling mewarisi setelah kematian seseorang.

Orang tua mengharapkan kebaikan bagi anak-anaknya (keturunannya) dan berharap amalannya akan berkelanjutan kepada anak-anaknya yang merupakan cermin dari eratnya hubungan perasaan mereka. Hal tersebut dapat dilihat berdasarkan hadist $\mathrm{Nabi}$ SAW yang terkenal yang 
diriwayatkan dari A bu Hurairah :

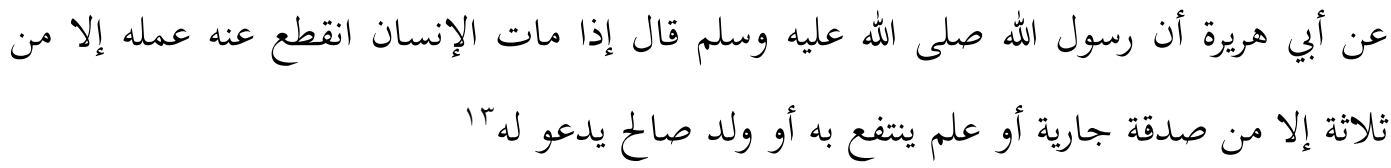

Bentuk kemaslahatan yang kedua adalah diberikan kepada keluarga terdekat. Oleh karena itu Islam menganjurkan agar memberikan nafkah kepada orang lain yang dimulai dari keluarga yang terdekat. Bentuk kemaslahatan yang ketiga adalah bagi masyarakat yang berdampak pada sistem distribusi. Warisan merupakan faktor yang sangat berperan dalam pemerataan kekayaan, perluasan dan pemindahan dari seorang pemilik kepada beberapa orang yang ketentuan pembagiannya telah ditentukan oleh Allah dalam al-Quran.

2. Nilai Keadilan

Kebebasan dalam Islam tidak bersifat mutlak. Oleh karena itu, meskipun seseorang diperbolehkan memiliki namun ada ketentuan batasannya atau aturan dalam memperoleh, mengembangkan dan mengkonsumsi harta yang dimilikinya. I slam juga mewajibkan setiap orang untuk mengeluarkan bagian tertentu dari harta yang dimilikinya.

$\mathrm{Hal}$ di atas dimaksudkan karena pada dasarnya manusia sangat senang mengumpulkan harta sehingga dalam pembelanjaan hartanya terkadang ia berlaku boros dan bersifat kikir. Oleh karena itu I slam memberikan perhatian mengenai keadilan dan larangan berbuat zalim (Q.S 42: 20, ...sesungguhnya Dia tidak menyukai orang-orang yang zalim) A yat yang ditegaskan dalam al-Qur'an yakni seorang M uslim tidak diperbolehkan berbuat zalim terhadap orang Iain termasuk lingkungannya. Kaitannya dengan distribusi pendapatan jika dalam pendistribusian pendapatan dilakukan dengan tidak adil maka akan menimbulkan keresahan dan protes dari pemilik faktor produksi. Oleh karena itu pembagian pendapatan harus diberikan sesuai dengan prinsip-prinsip keadilan.

\section{Sektor-sektor Distribusi Pendapatan}

1. Distribusi Pendapatan dalam K onteks Rumah Tangga

Mengingat nilai-nilai Islam merupakan fakror endogen dalam rumah tangga seorang muslim, maka haruslah dipahami bahwa seluruh proses aktivitas ekonomi di dalamnya, harus dilandasi legalitas halal haram mulai dari: produktivitas, hak kepemilikan, konsumsi, transaksi dan investasi. A ktivitas yang terkait dengan aspek hukum tersebut kemudian menjadi muara bagaimana seorang muslim melaksanakan proses distribusi pendapatannya.

Distribusi pendapatan dalam konteks rumah tangga akan sangat terkait dengan terminologi shadaqah. Pengertian shadaqah di sini bukan berarti sedekah dalam konteks

\footnotetext{
${ }_{13}$ M uslim ibn al-Hujjaj A bu al-Hasan al-Qusyairi al-Nisaburi, Shahih al-M uslim, Juz 3 (Beirut: Dar Ihya alTurats al-'A rabi, tt), 1255
} 
pengertian bahasa Indonesia. Karena shadaqah dalam konteks terminologi al-Quran dapat dipahami dalam dua aspek, yaitu: ${ }^{14}$

Pertama, instrumen shadaqah wajibah (wajib dan khusus dikenakan bagi orang muslim) adalah:

1. Nafaqah: kewajiban tanpa syarat dengan menyediakan semua kebutuhan pada orangorang terdekat.

2. Zakat: kewajiban seorang muslim untuk menyisihkan sebagian harta miliknya, untuk didistribusikan kepada kelompok tertentu (delapan asnaf).

3. U dhiyah: qurban binatang ternak pada saat hari tasyrik perayaan Idhul A dha.

4. Warisan: pembagian asset kepemilikan kepada orang yang ditinggalkan setelah meninggal dunia.

5. M usaadah: memberikan bantuan kepada orang lain yang mengalami musibah.

6. Jiwar: bantuan yang diberikan berkaitan dengan urusan bertetangga.

7. Diyafah: kegiatan memberikan jamuan atas tamu yang datang.

Kedua, instrumen shadaqah nafilah (sunah dan khusus dikenakan bagi orang muslim) adalah: ${ }^{15}$

1. Infaq: sedekah yang dapat diberikan kepada pihak lain jika kondisi keuangan rumah tangga muslim sudah berada di atas nisab.

2. A qiqah: memotong seekor kambing untuk anak perempuan dan dua ekor kambing untuk anak laki-laki yang baru lahir.

3. Wakaf: memberi bantuan atas kepemilikannya untuk kesejahteraan masyarakat umum, asset yang diwakafkan bisa dalam bentuk asset materi kebendaan ataupun asset keuangan.

K etiga: Instrumen term had/ hudud (hukuman)

1. Kafarat: tebusan terhadap dosa yang dilakukan oleh seorang muslim, misal melakukan hubungan suami istri pada siang hari pada bulan Ramadhan.

2. Dam/diyat: tebusan atas tidak dilakukannya suatu syarat dalam pelaksanaan ibadah, seperti tidak melaksanakan puasa tiga hari pada saat melaksanakan ibadah haji, dendanya setara dengan seekor kambing.

3. Nudzur: perbuatan untuk menafkahkan atas pengorbanan sebagian harata yang dimilikinya untuk mendapatkan keridhaan Allah SWT, atas keberhasilan pencapaian sesuatu yang menjadikan keinginannya.

Berbeda dengan ajaran ekonomi manapun, ajaran Islam dalam mendistribusikan pendapatan rumah tangga mengenal skala prioritas yang ketat. B ahkan berkaitan dengan kewajiban zakat, ajaran Islam memberikan sejumlah persyaratan (karakteristik khusus) pada aset wajib zakat. Dari kepemilikan aset yang dimiliki, pertama yang harus didistribusikan (dikeluarkan) dari jumlah seluruh asset adalah kebutuhan keluarga, dan mendahulukan membayar hutang.

Kemudian dari sisa aset yang ada, yang harus diprioritaskan adalah distribusi

${ }^{14}$ A fzalur Rahman, Economic Doktrines of Islam, 94

${ }^{15}$ A diwarman A . K arim, Ekonomi M ikro Islami (J akarta: PT. Raja Grafindo Persada, 2008), 222 
melalui instrumen zakat. Namun harus dilihat terlebih dahulu karakter dari sisa asset tersebut, ada 3 yaitu:

1. A pakah asset itu di atas nisab.

2. Kepemilikan sempurna.

3. Sudah genap satu tahun kepemilikan dan potensi pruduktif.

Jika diperhatikan dengan seksama, setiap instrumen yang ditawarkan Islam dalam memecahkan permasalahan ketidaksetaraan pendapatan (inequality income) antar rumah tangga, pada dasarnya dapat disesuaikan dengan daur hidup pencarian kekayaan manusia secara umum, yaitu: ${ }^{16}$

Pertama, accumulation phase (fase akumulasi), yaitu tahap awal sampai pertengahan karier. Pada fase ini individu mencoba meningkatkan asetnya (kekayaan) untuk dapat memenuhi kebutuhan jangka pendek. Secara umum, pendapatan bersih dari individu dalam fase ini tidaklah besar. Untuk itu, ekonomi rumah tangga dapat menfokuskan pengeluarannya khusus untuk meningkatkan produktivitasnya dan memenuhi kebutuhan keluarganya atau nafaqah.

Kedua, consolidation phase (fase konsolidasi). Individu yang berada dalam fase ini biasanya telah melalui pertengahan perjalanan kariernya. Dalam fase ini biasanya pendapatan melebihi pengeluaran. Mereka yang ada di fase ini dapat meninvestasikan dananya untuk tujuan jangka panjang. Untuk itu, pada setiap kelebihan asetnya, individu dapat melakukan kewajiban zakat dan instrument-intrumen lainnya yang lebih terkait kepada perayaan rasa syukur seperti udhiyah, aqiqah dan infaq

Ketiga, spending phase. Fase ini secara umum dimulai pada saaat individu memasuki masa pensiun. Kebutuhan akan biaya hidup harian mereka peroleh dari investasi yang mereka lakukan lakukan pada dua fase sebelumnya. Pada fase ini, kewajiban untuk memberikan nafkah keluarga akan berkurang, seiring dengan semakin dewasanya anak yang menjadi tanggungan. Untuk itu, jika individu pada fase ini masih mempunyai produktifitas tinggi (kelebihan materi), maka kesempatan terbuka bagi individu tersebut untuk memberikan sebagian hartanya melalui instrumen yang mengarahkan kepada kepentingan umum (sosial). Seperti wakaf dan menuliskan wasiat, kedua instrumen tersebut lebih dekat kepada pengertian investasi akhirat. Jika tidak demikian, maka yang harus dipersiapkan adalah warisan.

2. Distribusi Pendapatan Sektor Industri

Distribusi pendapatan sektor industri meliputi mudharabah, musyarakah, upah maupun sewa. M udharabah merupakan bentuk kerja sama antara pihak pemodal (shahib al-mal) dan pengusaha (mudharib) dengan sistem bagi hasil. Pemodal, sebagai pihak yang mempunyai kelebihan harta, namun tidak punya kesempatan ataupun waktu untuk mengembangkan hartanya. Ia mendistribusikan sebagian kekayaanya kepada pengusaha dalam bentuk investasi jangka pendek ataupun jangka panjang secara mudharabah (bagi hasil). Sedangkan musyarakah merupakan kerja sama bebrapa pemodal dalam mengelola suatu usaha dengan sistem bagi hasil. Distribusi kekayaan seperti ini merupakan bentuk

\footnotetext{
${ }^{16}$ M ustafa Edwin Nasution, Pengenalan Eksklusif Ekonomi Islam (Jakarta: Kencana, 2010), 142
} 
distribusi dalam bentuk investasi, baik jangka pendek maupun jangka panjang. Dengan berhimpunnya beberapa pemodal dalam mendirikan suatu perusahaan seperti PT atau pun CV tentu akan memberikan peluang kepada masyarkat masyarakat menjadi tenaga kerja pada perusahaan tersebut dan memberikan kesempatan kepada mereka untuk mendapat pendapatan dalam bentuk upah atau gaji. Di samping itu, rumah tangga yang mempunyai lahan ataupun bangunan yang digunakan perusahaan juga akan mendapatkan pendapatan dalam bentuk sewa. ${ }^{17}$

3. Distribusi Pendapatan dalam K onteks Negara

Prinsip-prinsip ekonomi yang dibangun di atas nilai moral Islam mencanangkan kepentingan distribusi pendapatan secara adil. Para sarjana muslim banyak membicarakan objektivitas perekonomian berbasis Islam pada level negara terkait dengan penjaminan level minimum kehidupan bangsa bagi mereka yang berpendapatan di bawah kemampuan. Negara wajib bekerja untuk meningkatkan kesejahteraan materi bagi lingkungan sosial maupun individu dengan pemafaatan sebesar-besarnya atas sumber daya yang tersedia. Karena itu negara wajib mengeluarkan kebijakan yang mengupayakan stabilitas ekonomi, kesetaraan, ketenagakerjaan, pembangunan sosial ekonomi, dan lain sebagainya. ${ }^{18}$ Negara juga bertanggung jawab atas manajemen kepemilikan publik yang pemanfaatannya diarahkan untuk seluruh anggota masyarakat. ${ }^{19}$

Dalam pengelolaan sumber daya, negara harus mampu mendistribusikan sumber daya yang ada dengan baik. Artinya, kesempatan tidak hanya diberikan kepada sekelompok tertentu saja. K ebijakan distribusi menganut kesamaan dalam kesempatan kerja, pemeratan kesejahteraan dan pemanfaatan lahan yang menjadi hak publik, pembelaan kepentingan ekonomi untuk kelompok miskin, menjaga keseimbangan sosial investasi yang adil dan merata.

A jaran Islam memberikan otoritas kepada pemerintah dalam mengatur pendapatan dan pengeluaran negara. Pemerintah diberikan kewenangan mengatur pendapatan melalui penarikan pajak pendapatan BUM N dan sebagainya. Di samping itu, pemerintah juga diberikan kewenangan untuk membelanjakan anggaran untuk kepentingan bangsa dan negara, misalnya pemberian subsidi, pembangunan infrastruktur dan lain sebagainya. Semua keistimewaan tersebut harus diarahkan untuk memenuhi kepentingan bangsa dan negara. ${ }^{20}$

Penguasaan pengelolahan lahan publik oleh pihak swasta diarahkan untuk tidak merusak kepentingan banyak pihak, misalnya tidak dibenarkan pemerintah memberikan hak usaha penggalian lahan yang banyak mengandung barang tambang kepada sektor swasta, jika aktivitas tersebut kemudian menimbulkan ekses negatif seperti kesenjangan atau terkonsentrasinya kekuatan kapital kepada kelompok atau pihak wasta tertentu. Kalaupun karena kepentingan maslahat tertentu (seperti penguasaan teknologi

\footnotetext{
${ }^{17}$ R ozalinda, Ekonomi Islam, Teori dan A plikasinya Pada A ktivitas Ekonomi, 140

${ }^{18}$ A diwarman A . Karim, Ekonomi M ikro Islam, 210

${ }^{19}$ Rozalinda, Ekonomi Islam, T eori dan A plikasinya pada A ktivitas Ekonomi, 139

20 Ibid.
} 
misalnya), sehingga lahan tersebut tidak dapat digarap oleh publik, maka kebijakan pemerintah harus menetapkan tarif zakat sebesar $20 \%$ per tahun. ${ }^{21}$

Dalam ekonomi pasar Islam, mekanisme pasar menekan seminimal mungkin peranan pemerintah (command economics). Pembenaran atas diperbolehkan pemerintah masuk sebagai pelaku pasar (intervensi) hanyalah jika pasar tidak dalam keadaan sempurna, dalam arti ada kondisi-kondisi yang menghalangi kompetisi yang fair terjadi atau distribusi yang tidak normal atau dengan kata lain mengupayakan tidak terjadinya market failure. Sebagai contoh klasik dari kondisi market failure antara lain: barang publik, eksternalitas, (termasuk pencemaran dan kerusakan lingkungan), asymetrik information, biaya transaksi, kepastian institusional serta masalah dalam distribusi. Dalam masalah yang lebih singkat, masuknya pemerintah adalah untuk menjamin fairness dan keadilan. ${ }^{22}$

Kepentingan negara (pemerintah) dalam distribusi pendapatan di pasar adalah bagaimana pemerintah dapat menjamin pendapatan (barang dan jasa) seluruh bangsanya di atas kemampuan materi limit ofpittance (nisab) dengan indikator yang mengacu kepada kepentingan maslahat dari maqasid al-syariah. Konsep distribusi kemudian memanfaatkan instrumen harga untuk menentukan nilai barang maupun jasa yang ditawarkan di pasar. Dalam tataran teoritis-normatif, hukum permintaan dan penawaran di pasar sangat berperan dalam menentukan pendapatan, hal ini karena pendapatan di pasar direpresentasikan oleh harga yang berlaku sebagai alat tukar atas penggunaan jasa atau pun aneka ragam produk. Dengan demikian, setiap pendapatan yang diterima berlaku sebagai insentif dari kepemilikan dan pengembangan faktor-faktor produksi.

Dalam kajian ekonomi konvensional, teori keadilan pemerataan pendapatan berdiri di atas empat hal, yaitu: prinsip-prinsip kebutuhan dasar, prinsip-prinsip efesiensi, prinsip-prinsip equity yang menghabiskan proposional dan tanggung jawab social dan prinsip-prinsip yang menggantungkan permasalahan keadilan atas dasar hasil evaluasi keadaan dan situasi yang berlaku. Sedang di pihak lain, ajaran islam menjelaskan bahwa selain mengupayakan mekanisme pasar yang berada dalam frame halal-haram, ajaran Islam juga menganut keyakinan adanya tanggung jawab personal terhadap kesejahteraan orang lain serta batas batas kesejahteraan yang seharusnya dinikmati pelaku pasar susuai dengan aturan syari'ah. Untuk hal tersebut, instrumen dikedepankan adalah zakat yang didisrtibusikan secara produktif. ${ }^{23}$

Kemudian dalam Kebijakan ekonomi politik diarahkan untuk melayani kepentingan individu dan umum sekaligus. Model ini memfokuskan kepada keseimbangan, dan harmonisasi kedua kepentingan tersebut. Kebijakan politik ekonomi Islam juga melayani kesejahteraan materiil dan kebutuhan spiritual. Aspek politik ekonomi politik Islam yang dilakukan oleh para penguasa adalah dalam rangka mengurusi dan melayani ummat. Seperti yang dinyatakan dalam kaidah fiqhiyyah:

\footnotetext{
${ }^{21}$ M ustafa Edwin Nasution, Pengenalan Eksklusif Ekonomi Islam, 149

22 lbid., 151

${ }^{23} \mathrm{Ibid} ., 153$
} 


$$
\text { تصرف الامام على الرعية منوط بالمصلحة24 }
$$

"Tindakan seorang penguasa terhadap rakyatnya harus senantiasa mengacu kapada kemaslahatan".

Dalam sejarah Islam, aspek ekonomi politik yang dilakukan oleh khalifah adalah dalam rangka mengurusi dan melayani umat. Kemudian dilihat dari bagaimana Islam memecahkan problematika ekonomi, maka berdasarkan kajian fakta permasalahan ekonomi secara mendalam terungkap bahwa hakikat permasalahan ekonomi terletak pada bagaimana distribusi harta dan jasa di tengah-tengah masyarakat sehingga titik berat permasalahan ekonomi adalah bagaimana menciptakan suatu mekanisme distribusi ekonomi yang adil.

Pada masa kenabian dan kekhalifahan, kaum Muslim menerapkan beberapa instrumen dalam kebijakan fiskal yang diselenggarakan pada baitul maal. Dari berbagai macam instrumen, pajak diterapkan atas individu (jizyah dan pajak khusus muslim), tanah kharaj, dan usyur (cukai) atas barang impor dari Negara yang mengenakan cukai terhadap pedagang kaum muslimin, sehingga tidak memberikan beban ekonomi yang berat bagi masyarakat. Pada saat perekonomian sedang krisis yang membawa dampak terhadap keuangan negara karena sumber-sumber penerimaan terutama pajak merosot seiring dengan merosotnya aktifitas ekonomi, maka kewajiban-kewajiban tersebut beralih kepada kaum muslimin. Misalnya krisis ekonomi yang mengakibatkan warga negara jatuh miskin otomatis mereka tidak dikenai beban pajak baik jizyah maupun pajak atas orang Islam. Sebaliknya, mereka akan disantuni negara dengan biaya yang diambil dari orang-orang muslim yang kaya, yaitu zakat.

Dalam kebijakan fiskal menurut Islam, selain pajak memang dikenal pula zakat yang merupakan salah satu inti ajaran Islam. Islam menentukan infak dan mewajibkan zakat kepada orang kaya. Zakat merupakan sarana penyucian diri dari harta karena pada dasarnya dalam harta manusia terdapat hak orang lain yang harus diberikan. Negara berhak mengumpulkan zakat dan menyalurkannya kepada yang berhak menerimanya serta memaksa siapa saja yang tidak mau mengeluarkan zakat dan mengingatkan para wajib zakat. Untuk melakukan tugas tersebut, negara dapat membuat undang-undang dan membentuk lembaga yang bertugas mengurus masalah tersebut dan juga harus memegang amanah (mengelola zakat) dan menyampaikannya kepada yang berhak serta mencegah semua bentuk kezaliman dan praktik yang dilarang oleh Islam seperti: penimbunan, mempermainkan harga dan perilaku pemborosan ${ }^{25}$.

Dari uraian tersebut dapat disimpulkan bahwa dalam Islam negara berhak menarik pajak dan disalurkan kembali berupa fasilitas dari pajak dan hanya dalam rangka tugas pemerintahan. Demikian pula negara dapat mengelola dan menyalurkan zakat, sehingga dengan demikian negara dapat berperan sebagai agen yang efektif yang mampu

${ }^{24} \mathrm{Al}$-Imam Jalaluddin A bdurrahman ibn A bu Bakar as-Suyuti, A sybah wa al-Nadzair fi al-Furu' (Semarang: M aktabah U saha K eluarga, TT), 83

${ }^{25}$ Deky A nwar, Ekonomi M ikro Islam (Palembang: Noer Fikri Offset, 2014), 246 
menerapkan aturan-aturan dalam al-Qur'an dan al-Hadits serta pedapat ulama yang berhubungan dengan prinsip-prinsip distribusi pendapatan.

Dengan demikian jika dikaitkan dengan keadaan bangsa Indonesia yang sampai detik ini masih ada kesenjangan antara yang kaya dengan yang miskin itu dikarenakan masih belum meratanya distribusi pendapatan. Maka salah satu alternatif dalam memecahkan masalah ini adalah mengoptimalkan peran Badan A mil Zakat dan Lembaga A mil Zakat yang ada. Kesadaran masyarakat Indonesia yang notabene mayoritas beragama Islam, masih kurang untuk melakukan zakat, terutama zakat penghasilan, yaitu $2,5 \%$ dari pendapatannya. Zakat yang 2,5\% saja masih sulit untuk dilaksanakan, apalagi shodaqoh yang hukumnya sunnah. Maka jika BAZIS (Badan A mil Zakat Infaq dan Shodaqoh) dan LAZIS (Lembaga A mil Zakat, Infaq dan Shadaqah) dioptimalkan dan dibuat undang-undang yang mengakibatkan dikeluarkannya zakat tersebut penulis yakin tidak ada lagi penduduk miskin di Negara kita tercinta ini.

\section{Penutup}

Distribusi pendapatan merupakan bagian yang penting dalam membentuk kesejahteraan. Dampak dari distribusi pendapatan bukan saja pada aspek ekonomi, melainkan juga aspek sosial dan politik. Oleh karena itu, Islam memberi perhatian lebih terhadap distribusi pendapatan dalam masyarakat. Islam memang mengakui hak milik pribadi, akan tetapi hak milik pribadi tersebut harus bisa didistribusikan dengan baik. Milik pribadi tersebut dipergunakan untuk nafkah diri dan keluarga dalam menjalani kehidupan, berinvestasi untuk modal produksi sehingga bisa memberikan kesempatan kerja bagi orang lain, memberikan pertolongan untuk orang lain melalui zakat infaq dan shodaqoh. Dengan cara seperti ini, maka harta tidak hanya berputar pada orang kaya saja yang mengakibatkan adanya kesenjangan dalam kehidupan sosial.

Melihat penduduk Indonesia yang mayoritas beragama Islam, sementara di sisi lain masih banyaknya kesenjangan antara yang kaya dan miskin, maka zakat, infaq dan shodaqoh merupakan hal yang menarik untuk dikaji dan diterapakan sebagai kebijakan fiskal atau diberdayakan melalui BAZ (B adan A mil Zakat) dan LAZ (Lembaga A mil Zakat) yang ada di Indonesia. Peran BAZ dan LAZ perlu dioptimalkan dalam masalah pemberdayaan zakat infaq dan sodaqoh ini karena meskipun penduduknya mayoritas muslim ternyata mereka banyak yang enggan mengeluarkan derma tersebut. K alaupun sebagian orang kaya ada yang mengeluarkan zakat, infaq, dan sodaqoh dengan diberikan secara langsung oleh dirinya kepada fakir miskin. Pemberdayaan melalui BAZ dan LAZ akan lebih baik daripada dikeluarkan secara individu dikarenakan akan terkoordinasi, baik dalam penarikan maupun penyalurannya.

Oleh karena Negara bertanggung jawab terhadap mekanisme distribusi, maka pemerintah mempunyai tanggung jawab dalam penataan masalah ini. Peran BAZ dan LAZ harus dioptimalkan demi kepentingan kesejahteraan masyarakat. Penulis yakin, jika zakat diberdayakan melalui peran BAZ dan LAZ yang optimal, maka tidak akan ada penduduk miskin di Indonesia ini. 


\section{Daftar Rujukan}

A far, M uhammad,at-T auzi', Cairo: Daar al Fath lil Ilaam al A raby, 1996

Ahmad, al Mausû'ah al Fiqhiyyah al Kuwaitiyyah, Kuwait: Wazaarat al Awqaaf wa as Syu'uun al Islaamiyyah, 1997

A I-Ghazali, Hawla al M anhaj al Islâmy fi at Tanmiyah al Iqtishâdiyyah, Cairo: Dar al Wafaa, 1989

Al-Nisaburi, Muslim ibn al-Hujjaj Abu al-Hasan al-Qusyairi, Shahih al-Muslim, Juz 3, B eirut: Dar Ihya al-T urats al-'A rabi, tt

A I-Zuhaili, Wahbah, al Fiqh al Islâmi wa A dillatuhû, Damaskus: Dar al Fikr, 1985

Ali al-Jarhi, Mabid and A nas Zarqa, M uhammad, Redistributive Justice in a Developed Economy: An Islamic Perspective, paper presented at $6^{\text {th }}$ International Conference on Islamic Economics and Finance, Jakarta: B ank Indonesia, 2005

A s-Syarbâshî, A hmad, al M u'jam al I qtishâdî al Islâmî, Cairo : Dar al Geil, 1981

Campbell R. M acConnel and Stanley R. B rue, Economics Principles, Problems, and Policies, New Y ork: M cGraw-Hill Higher Education, 2002

Chapra, U mer, the Future of E conomics: A n Islamic Persfective, terjemahan Indonesia M asa Depan IImu Ekonomi; SebuahT injauan Islam, Jakarta: Gema Insani Press, 2001

Edwin Nasution, M ustafa, Pengenalan Eksklusif Ekonomi Islam, Jakarta: K encana, 2010 Karim, A diwarman A ., Ekonomi M ikro Islami, Jakarta: PT. Raja Grafindo Persada, 2008 W inardi, Kamus Ekonomi, B andung: CV . M andar M aju, 1989 